\title{
The Influence of Education-Information-Communication (EIC) Based on Karo Culture for the Early Detection of Cervical Cancer at the Karo Region
}

\author{
Elisabeth Surbakti ${ }^{1} \&$ Susy Adrianelly Simaremare ${ }^{2}$ \\ ${ }^{1}$ Midwifery Department of the Ministry of Health Medan Polytechnic, North Sumatera, Indonesia \\ ${ }^{2}$ Dental Nursing Department of the Ministry of Health Medan Polytechnic, North Sumatera, Indonesia \\ Correspondence: Elisabeth Surbakti, Midwifery Department of the Ministry of Health Medan Polytechnic, North \\ Sumatera, Indonesia. Tel: 62-813-953-0920. E-mail: elisabethsurbakti@gmail.com
}

Received: December 19, 2018 Accepted: January 29, 2019 Online Published: February 27, 2019

doi:10.5539/gjhs.v11n3p129 URL: https://doi.org/10.5539/gjhs.v11n3p129

\begin{abstract}
Education, Information and Communication (EIC) based on Karo Culture on Knowledge and Attitude of Women of Childbearing Age for the Early Detection of Cervical Cancer at the Village of Cinta Rakyat, Merdeka District, Karo Region. Quasi experiment with non-equivalent pre-test and post-test, using a control group with the intervention of EIC based on Karo culture through counseling in Cinta Rakyat village, Merdeka district and Karo Regency. In order to know the influence of EIC based on Karo culture to knowledge and attitude, this research conducted an independent t-test with normality-test as starting point. This research also employed pair t-test to know two different variables: knowledge and attitude. Purposive sampling was conducted with univariate and bivariate data analysis. There is an influence of EIC based on Karo culture through composed songs and traditional dance called Landek on knowledge and attitude before and after the intervention $(p=0,000)$. This research found that there is an influence of counseling on knowledge and attitude before and after the intervention $(p=0,000)$. There is no difference between EIC based on culture through composed songs and dance, and counseling to increase knowledge $(p=0,498)$. However, EIC based on culture is more effective way than counseling to develop attitude toward cervical cancer prevention $(\mathrm{p}=0,027)$. This research, therefore, argues that health officers/Promkes at the Health Office and at the center of community health/PUSKESMAS are expected to conduct counseling on cervical cancer using composed songs and dance (Landek) for prevention strategy, especially in the area of the center of community health in Karo District.
\end{abstract}

Keywords: cervical cancer, EIC based on Karo culture, early detection of cervical cancer

\section{Introduction}

Cervical cancer is a significant problem of public health, especially in Indonesia as the second causes of death in women after breast cancer. According to Sulistiowati (2015), there are approximately 370,000 new cervical cancer cases in developing countries. In Indonesia, it is predicted that there are 90 to 100 new cervical cancer cases among 100,000 inhabitants annually. In other words, there are 180,000 new cases per year (Sari, 2012)

In developing countries such as in Indonesia, almost eighty to ninety percent of patients with severe cervical cancer are difficult to be cured. The reason is that people who have cervical cancer visit hospitals already in the advance stage (around 70\%). As a result, treating patients is often harder and likely to succeed, resulting the cancer cannot be cured.

People with cancer are often diagnosed too late due to the lack of symptoms. This results in an increase of patients every year and currently the disease also affects young people. A research was conducted by Surbakti, (2017) at Adam Malik Public Hospital in relation to the factors of affecting the delay of cervical cancer patients to visit to the health centre. The research found that $70.6 \%$ of patients come to hospitals already at the advance stage, meaning that there is a very low of self-awareness in examining their health.

In addition, a lack of knowledge and attitude of the community in detecting the cancer is another problem, although it is easier to cure the cancer when it is still found at the early stage. The benefit of detecting the cancer at the early stage is that the maternal mortality will decrease. Almost $99.7 \%$ of cervical cancers are related to the 
infection of Human Papilloma Virus (HPV), as one of the most common Sexually Transmitted Diseases (STDs) in the world. All women are at risk of HPV, regardless their age and background.

In Indonesia, the program on early detection of cancer has not been a priority for the government. In addition, Non-Government Organizations (NGOs), such as Indonesian Cancer Foundation/Yayasan Kanker Indonesia (YKI), have a limitation to conduct the program or sometime the program is sporadic in the implementation. It has been argued that an ideal way for Indonesia in this matter is to have a better early detection program by setting up a low cost and an effective technology. This is because Indonesia has a huge area, consisting thousands of islands with a rapid growing population and high mobility, inadequate communication, low economic income and education as well as lack of awareness on the health issues (Medical Faculty of the University of Indonesia, 2007).

Moreover, there is also a problem on low commitment of women to have an early detection for cervical cancer. This is relevance to previous research such as conducted by Sulastri (2014), Khoiron Nur (2014), Ismawarti (2011). Those research state that there is a culture of shame on gynecological examination for women. It is because the examination relates to female privacy organ. Moreover, there is a fear of the examination result when women are detected having cervical cancer. In addition, there is a lack of knowledge of women of childbearing age, especially the information on the procedure of the Visual Inspection of Acetic acid (VIA) and cervical cancer. It is $50 \%$ of new cases of cervical cancer related to women who have not previously done early detection of cervical cancer. According to Ministry of Health (MOH) in 2005, if women have awareness and willingness on early detection or examination of cervical cancer, the problem of cervical cancer in Indonesia will be reduced.

Furthermore, a number of women of childbearing age which have screening and examination are still low. A high undetectable rate of patients is because women are less informed and lack of awareness and knowledge about the early detection program on cervical cancer.

The EIC based on Karo culture is believed to improve knowledge and attitude of the community, especially for women in preventing from cervical cancer. Thus, this approach should be developed since the EIC is more effective and efficient way. EIC in the health sector using cultural approach especially Karo culture is expected to bring successful impacts to the effort of the cervical cancer prevention in women, especially for women of childbearing age which are at risk. Therefore, the researcher is interested in conducting a research with the title, "the influence of EIC based on Karo culture on knowledge and attitude of women of childbearing age on the early detection of cervical cancer at the village of Cinta Rakyat, Merdeka District, Karo Region".

The purpose of this research is to analyze the influence of EIC based on Karo Culture to knowledge and attitudes of women of childbearing age on the early detection of cervical cancer at the village of Cinta Rakyat, Merdeka district, Karo region. This study aims to answer the following research questions:

1. What is an influence of EIC based on Karo culture on knowledge and attitude of women of childbearing age for the early detection of cervical cancer.

2. What is an influence of counseling on knowledge and attitude of women of childbearing age for the early detection of cervical cancer.

3. What is an EIC based on culture is more effective way than counseling of women of childbearing age in increasing knowledge and attitude on cervical cancer.

\subsection{Study Significan}

Significant for this study arises from the fact that the prevalence of cervical cancer in Indonesia is high, with an incidence of 23.4 / 100,000 population and is the number one killer for Indonesian women. (Dwipoyono, 2009; Suwiyoga, 2016). The high number of cervical cancer cases in Indonesia has made WHO put Indonesia as the country with the highest number of cervical cancer sufferers in the world. One of the drivers of this high rate is due to the absence of an early monitoring process. Most cervical cancer sufferers only realize when the condition is severe or severe. (Nurwijaya, 2013). preventive efforts are very necessary in preventing cervical cancer. The results of this study will reveal the importance of IEC as a health promotion effort in the prevention of cervical cancer, through local culture (Karo culture) by singing and dancing (hedgehog), so that in the end the Fertile Age Woman (WUS) will detect early cancer for prevention.

\subsection{Literature Review}

The early detection on cervical cancer is a form of innovative breakthrough in the healthcare and medical field. This aims to recognize precancerous signs of cervical cancer at the earliest stage. This program can be performed by health professionals such as general practitioners and midwives in public health centers. The benefit of the examination program is that the cost is relatively cheap and affordable for people lower income. The result of the 
examination or screening can be directly seen by the examiners' eyes. This VIA examination can reduce the number of patients with cancer entering hospitals at the very late stage. In other words, early VIA examination and screening can reduce the mortality and morbidity of women of childbearing age from cervical cancer (Vanesa, 2018; Romadani, 2014)

A lot of women in developing countries, including Indonesia have lack of Education, Information and Communication (EIC) program on cervical cancer because they have a lack of knowledge and low socio-economic status. As a result, although the government policy on the price of the VIA examination in all health centers is very affordable, still not many women utilize the service.

In the community, EIC focuses on three levels of prevention: primary, secondary and tertiary together with the community empowerment. According to Rappaport (1984 in Helvie, 1998), community empowerment is a process whereby individuals, organizations and communities gain control over their lives. People in the community are required to change their life and their environment to be sustainable. The community empowerment is in line with the government program on the prevention of cervical cancer through the empowerment of women and families improving their knowledge and healthy behavior (Rahmiyati, 2016; Pimple, 2016).

Community empowerment through EIC based on culture in dealing with cervical cancer is a way to prevent and to treat the cancer at the earliest stage. Using EIC method, it is expected to give optimal result because the method can be developed with educational activities in the form of counseling, sharing and discussion. Thus, the EIC has the dynamic process within the group based on local culture (Giersing, 2016)

In the Eastern norms and culture such as in Indonesia, there is an attitude and perception which hinder women to have openness to medical examination in relation to their reproductive health. As a result, most patients with cancer come to medical doctors at very late stage causing the cancer harder to be cured (Darmayanti, 2016; Mannava, 2015).

\section{Methods}

\subsection{Research Design}

This research is a quasi-experiment with non-equivalent pre-test and post-test with a control group design. This study compares between two different groups; first is the group with intervention of EIC based on Karo culture and the second group is a group given counseling as a control group.

\subsection{Research Setting}

This research was conducted in the village of Cinta Rakyat, Merdeka district, Karo region. Women of childbearing age in the control and intervention groups have similar characteristics, geographic and social aspects.

\subsection{Population and Sample}

Population for this research was women who have a risk of cervical cancer in the village of Cinta Rakyat, Merdeka district, Karo Regency. The sample in this research is women of childbearing age which become targets of VIA in Cinta Rakyat village, Merdeka district, Karo Regency. The inclusive criteria of women of childbearing age are women who have been married, healthy and have willingness to be respondents. The exclusive criteria of women of childbearing age are unmarried women and unwillingness to be respondents.

This research employed purposive sampling criteria and therefore sampling technique for this research was purposive sampling with several criteria and therefore, women who met criteria were chosen to be respondents. The number of samples for this study was based on the formula, as follows: $=76.26 \approx 77$. Thus, the researcher obtained a large of sample with 77 respondents. To avoid the dropped out or loss in the follow up of sample, the sample size was 80 respondents with 40 people were in intervention groups and 40 people were in the control group.

\subsection{Measurement}

This research used secondary and primary data. Questionnaires were developed by the researcher and they were checked in terms of validity and reliability. Data collection was started through distributing the pre-test questionnaires to both groups. The researcher, then, conducted EIC intervention to the group within 5 times, using Karo culture. While the control group was not given EIC so they were allowed to obtain information naturally.

Materials of EIC were based on Karo culture to overcome the problematic culture of shame, fear of positive results of the examination, fear with the early detection of cervical cancer using VIA method. So, the contents of EIC were: giving understanding, explaining symptoms and the risks of cervical cancer, cervical cancer prevention and VIA procedures. After EIC was conducted, the respondents from both groups were given post-test assessment. The 
research procedures are explained as follows:

Data collection was started by conducting preliminary survey or situational analysis. Detailed data collection of the research is described below: Basically, this research was conducted through three different stages:

Phase I: Situational or survey analysis to the research location to know the characteristics of population, their local customs and culture through annual party activities (annual work) at the research site.

Phase II: Determining of respondents.

Before the annual party (annual work), the researcher determined the intervention group and the control group, followed by giving them pre-test in order to obtain their knowledge and attitudes on the early detection of cervical cancer.

The intervention stage: EIC based on culture through composed songs and dance on preventing cervical cancer. IEC based on culture were delivered through dancing and sing a song in relation to the early detection of cervical cancer using jingle of IVA through Karo ethnic. It is the fact that dancing and singing are part of Karo culture. In order to practice IEC, the researcher provided trainings to women of childbearing age to sing and to dance based on Karo culture.

Therefore, in the event of the annual party (annual work), the researcher conducted EIC based on culture through dancing and singing. After a couple of times, the researcher repeated the similar activities to have better understanding on the meaning of songs and dance in relation to the prevention of cervical cancer.

Phase III: Post-test phase

This phase was conducted when the intervention was completed as well as the measurement of knowledge and attitude (post-test).

\subsection{Ethical Consideration and Data Collection Procedure}

Ethical approval for conducting this research was obtained from the University of North Sumatra, Faculty of Nursing. Permission to collect participant data was obtained from the head of Namorambe village and Namorambe Health Center, Deliserdang District. The study was conducted from May to October 2016. The purpose and procedure of the study were explained to the respondents, after which the researchers collected data in advance to fill out informed consent and were willing to become respondents without coercion, entirely voluntary and anonymous. Respondents can resign at any time without sanctions if they feel uncomfortable in the research process.

\subsection{Data Management and Analysis}

Firstly, the data which has been collected were processed and analyzed through the descriptive analysis. Secondly, the univariate analysis was employed to obtain the description of the frequency or large proportion of variables studied.

This analysis was conducted to know the influence of EIC based on culture on knowledge, attitude, and action before and after the intervention using paired t-test. Furthermore, to assess the effectiveness of EIC based on culture, independent t-test was employed. Because the data was not normally distributed, mann-whitney and wilcoxon-test were used.

Prior to the measurement of knowledge and attitudes of respondents about early detection of cervical cancer before and after EIC based on Karo culture through composed songs and dance, the first step was to test the reliability and validity of knowledge and attitude questions. Reliability and validity test were conducted in the village of Sada Arih of Merdeka, Karo district with respondents having similar characteristic with the research sample: women have not received intervention or program about early detection of cervical cancer.

\section{Results}

\subsection{Sosio-Demografi Charakteristics of Participants}

This research was conducted in the village of Merdeka and Cinta Rakyat. Merdeka village was as the control group of EIC through counseling, while Cinta Rakyat village was EIC based on Karo culture. From the interviews process and questionnaires to respondents which were women of childbearing age as the target of cervical cancer prevention, the characteristics of respondents can be detailed as follows: 
Table 1. The characteristic of EIC based on Karo culture as early detection of cervical cancer in Cinta Rakyat Village, Merdeka District, Karo Regency.

\begin{tabular}{|c|c|c|c|c|}
\hline \multirow{2}{*}{ Characteristic } & \multicolumn{2}{|c|}{ Intervention } & \multicolumn{2}{|l|}{ Control } \\
\hline & Frequency & $\%$ & Frequency & $\%$ \\
\hline \multicolumn{5}{|l|}{ Age (year) } \\
\hline$<20$ & 1 & 2.5 & 0 & 0 \\
\hline $20-34$ & 11 & 27.5 & 8 & 20 \\
\hline$>35$ & 28 & 70 & 32 & 80 \\
\hline \multicolumn{5}{|l|}{ Education Grade } \\
\hline Basic & 20 & 50 & 10 & 25 \\
\hline Elementary & 18 & 45 & 27 & 67.5 \\
\hline Advance & 2 & 5 & 3 & 7.5 \\
\hline \multicolumn{5}{|l|}{ Jobs } \\
\hline Housewife & 20 & 50 & 12 & 30 \\
\hline Farmer & 12 & 30 & 18 & 45 \\
\hline Government employee & 3 & 7.5 & 3 & 7.5 \\
\hline Entrepreneur & 5 & 12.5 & 7 & 17.5 \\
\hline \multicolumn{5}{|l|}{ The age of marriage } \\
\hline$<20$ years old & 17 & 42.5 & 8 & 20 \\
\hline $20-34$ years old & 23 & 57.5 & 30 & 77.5 \\
\hline $35>$ years old & 0 & 0 & 1 & 2.5 \\
\hline \multicolumn{5}{|l|}{ Paritas } \\
\hline Primipara & 2 & 5 & 2 & 5 \\
\hline Multipara & 30 & 75 & 31 & 77.5 \\
\hline Grand Multipara & 8 & 20 & 7 & 17.5 \\
\hline Total & 40 & 100 & 40 & 100 \\
\hline
\end{tabular}

From Table 1, it can be seen that the majority of respondents' age in the intervention group was at age $>35$ years old: $70 \%$ people in the intervention group and $80 \%$ in the control group, while the primary level of education in intervention group was $50 \%$ and $67.5 \%$ at the control group.

\section{Knowledge and Attitude of Women of Childbearing Age on Cervical cancer}

The result of knowledge level evaluation and attitude of women of childbearing age before and after giving EIC based on Karo culture in the intervention group and giving counseling in the control group can be seen in table below: 
Table 2. The distribution of knowledge and respondents' attitude, before and after EIC based on culture and based on counseling on the early detection of cervical cancer in the village of Cinta Rakyat, Merdeka district, Karo Regency

\begin{tabular}{|c|c|c|c|c|c|c|c|c|}
\hline \multirow{3}{*}{ Category } & \multicolumn{4}{|c|}{ Intervention (culture-based IEC) } & \multicolumn{4}{|c|}{ Control (Extension) } \\
\hline & \multicolumn{2}{|c|}{ Before } & \multicolumn{2}{|c|}{ After } & \multicolumn{2}{|c|}{ Before } & \multicolumn{2}{|c|}{ After } \\
\hline & f & $\%$ & f & $\%$ & f & $\%$ & f & $\%$ \\
\hline \multicolumn{9}{|c|}{ Knowledge } \\
\hline Good & 1 & 2,5 & 35 & 87,5 & 2 & 5,0 & 31 & 77,5 \\
\hline Fair & 6 & 15,0 & 6 & 15,0 & 8 & 20,0 & 6 & 15,0 \\
\hline Poor & 33 & 82.5 & 1 & 2,5 & 30 & 75,0 & 3 & 7,5 \\
\hline \multicolumn{9}{|l|}{ Attitude } \\
\hline Good & 0 & 0 & 36 & 90,0 & 1 & 2,5 & 32 & 80,0 \\
\hline Fair & 22 & 55,0 & 3 & 7,5 & 8 & 20,0 & 8 & 20,0 \\
\hline Poor & 18 & 45,0 & 1 & 2,5 & 31 & 77,5 & 0 & 0 \\
\hline Total & 40 & 40 & 100 & 100 & 40 & 100 & 40 & 100 \\
\hline
\end{tabular}

From Table 2 above, it can be seen that the level of knowledge of respondents before EIC based on culture is generally poor $(82.5 \%)$ and fair $(15,0 \%)$ and After EIC based culture, knowledge level of respondents rose up to good category $(87,5 \%)$ and it is still found poor on knowledge $(2,5 \%)$. In the control group with counseling is generally poor $(75,0 \%)$ and fair at $(20,0 \%)$. While with counseling, knowledge level rose up to good category $(77,5 \%)$ and at poor category was still found at $(7,5 \%)$.

The attitude of respondents before IEC based on culture, it is generally at fair category (55\%) and (45\%) at poor category. After being given EIC based on culture, the attitude of the respondents rose up to the good category or $(90,0 \%)$ while at poor attitude at around $(2,5 \%)$. Attitudes of respondents who were given counseling, generally also in the category fair at $(77,5 \%)$, but there are still $(20,0 \%)$ at the poor category. After being given counseling, the respondents' attitude is fair at around (80,0\%).

\section{The Influence of Giving EIC Based on Karo Culture and Counseling on Cervical Cancer}

The influence of giving IEC based on Karo culture dan on counseling on cervical cancer knowledge and attitude of women of childbearing age can be seen in the Table 3 below:

Tabel 3. The influence of IEC based on culture and counseling of knowledge and attitude of women of childbearing age of the early detection on cervical cancer in Cinta Rakyat village, Merdeka district, Karo regency

\begin{tabular}{|c|c|c|c|c|}
\hline \multirow{2}{*}{ Variable } & \multicolumn{2}{|c|}{ Intervention (culture-based IEC) } & \multicolumn{2}{|c|}{ Control (Extension) } \\
\hline & Mean & $\mathrm{P}$ value & Mean & $P$ value \\
\hline \multicolumn{5}{|c|}{ Knowledge } \\
\hline Before & 30,60 & $0.001^{\mathrm{a})}$ & 35,65 & $0.001^{a)}$ \\
\hline After & 36,75 & & 42,90 & \\
\hline \multicolumn{5}{|l|}{ Attitude } \\
\hline Before & 29,03 & $0.001^{\text {a) }}$ & 33,58 & $0.001^{\text {a) }}$ \\
\hline After & 34,38 & & 35,68 & \\
\hline
\end{tabular}

From Table 3, it can be seen that there is the influence of EIC based on culture and counseling on cervical cancer on knowledge and attitude of respondents before and after EIC based on Karo culture and given counseling, with $\rho<\alpha$ 0.05 . 


\section{Effectiveness of Giving EIC based on Karo Culture}

This part is to know the effectiveness of EIC based on Karo Culture and counseling through independent-test, with the following results:

Table 4. The Effectiveness of KIE Based Culture and Counseling about Early Detection of Cervical Cancer in Desa Cinta Rakyat Merdeka District Karo Regency

\begin{tabular}{|c|c|c|c|c|c|}
\hline Intervention & Levene Test & Mean & $\begin{array}{l}\text { Std. } \\
\text { Deviation }\end{array}$ & Mean Dif & Sig \\
\hline $\begin{array}{l}\text { Score of knowledge with IEC based on culture } \\
\text { Score of knowledge with counselling }\end{array}$ & 0,00 & $\begin{array}{l}36,75 \\
35,65\end{array}$ & $\begin{array}{l}5,88 \\
8,34\end{array}$ & $-2,45$ & 0,06 \\
\hline $\begin{array}{l}\text { Score of attitude with IEC based on culture } \\
\text { Score of attitude with counselling }\end{array}$ & 0,64 & $\begin{array}{l}39,38 \\
33,58\end{array}$ & $\begin{array}{l}2,44 \\
3,86\end{array}$ & 2,20 & 0,001 \\
\hline
\end{tabular}

From Table 4 above, it can be seen that the knowledge assessment turns out to the relative homogeneous data or assumption of the same variation $(\rho=0,000<\alpha 0.05)$ and the result of difference-test turns to $\rho=0.06>\alpha 0.05$ so Ho is accepted, meaning that there is no difference of the average between IEC based on culture and counseling in improving knowledge. While on the attitude assessment, it is relative homogeneous data or the assumption of the same variation $(\rho=0.640>\alpha 0.05)$ and the average difference-test results turned out to be $\rho=0.001<\alpha 0.05$ so Ho is rejected, meaning that there is an average difference between the IEC based on culture and counseling in improving attitudes. Thus, the IEC based on culture is more effective in improving attitudes than providing counseling.

\section{Discussion}

\subsection{The Characteristic of Respondents}

The data shows that the average age of the respondents was generally more than 35 years old, with 70 percent in the intervention group and 80 percent in the control group. Aida (2009) stated that many patients of cervical cancer are more than 40 years old, at $82.6 \%$ of people. In addition, Prananda and Rusda (2013) conducted a study on cervical cancer patients at Adam malik Hospital, finding that the patients who came to Adam Malik hospital commonly were already at the stage IIIb. Those patients were between 40 and 55 years old or 214 patients (58.3\%).

Furthermore, (Ulfah, 2016; Jiang, 2014) stated that the development of HPV into cervical cancer usually occurs after 10 or 20 years. Referring to Prananda's and Rusda's research, patients with cervical cancer at Adam Malik Hospital were infected with HPV virus at the age between 20 and 35 years old. In fact, every person who is married has a high risk for HPV virus infection. Previous studies show that cervical cancer patients are generally at the age below 40 years old. Therefore, respondents who are generally at the age group between 35 and 40 years old necessarily need to do early detection of cervical cancer.

Based on educational background, respondents generally have elementary school level background at around 50\% people and the primary and high school education background at around 45\%. According to Suryandari (2014) research, the most cervical cancer patients have primary and high school educational background, it is around 48.5\%. Prananda and Rusda (2013) found the similar patent of patients' educational background where people with cervical cancer have primary and high school level of educational background with $52.7 \%$. The level of education is often associated with the level of understanding or ability of a person in receiving educational information, guidance and a particular goal. The higher of the level of education background, the more a person easily receive information and gain more knowledge. Conversely, lower educational background will impede the development of attitude and new values.

In this research, generally the respondents in the intervention group have occupation as farmers with around 30 percent people and as a house wife at around 50 percent. While in the control group, respondents who have house wife background are around 30 percent and 45 percent as farmers. A phenomenon in the Karo community is that in general respondents have background as housewife but they also become farmers. The fact is that people in the highlands of Karo mostly are farmers. Working as farmers often has difficulty to access health information. Work affects the individual income and working activities are also related to the social activities of individuals, so that by having a job, an individual person can easily know the information from outside i.e. both information related to 
common information and health information (Mirayashi, 2014).

Based on the marital age, generally the respondents in the intervention group are married, at 42.5 percent of people got married are at the age of 20 years old and there were 57.7 percent at around 20 and 34 years old. While in the control group, there were $77.5 \%$ of people who were married in the range between 20 and 24 years old and there are $20 \%$ people were married in the age of 20 years old. According to Aziz (2016), people who married before 15 years old have a high risk of cervical cancer, ten times greater than those who have sexual relations after 15 years old. Thus, at seventeen years old, people therefore need to have counseling and knowledge about reproductive health especially cervical cancer and genital hygiene. According to Anggraeni (2015), the lack of maintaining genital hygiene is suspected to be a cause of high risk on cervical cancer in women. Therefore, it can be stated that poor genital hygiene has a risk factor for cervical cancer.

Based on parity, respondents in the intervention group were mostly $75 \%$ of multipara and $20 \%$ grand multipara. While in the control group, $77.5 \%$ were multipara and $17.5 \%$ were grand multipara. According to Soedoko (2001), having children more than two will also increase the risk of cervical cancer. Manoppo, (2016), stated that the parity of having 4 to 6 children is at OR 1.3. The number of delivering babies and the cervical cancer is often associated with trauma to the birth canal or viral infection at the time of delivering babies (Manoppo, 2016).

\subsection{The Influence of EIC Based on Culture on Knowledge and Attitude}

From Table 2 above, it can be seen that the level of knowledge of respondents before EIC based on culture is generally poor $(82.5 \%)$ and fair $(15,0 \%)$ and After EIC based culture, knowledge level of respondents rose up to good category $(87,5 \%)$ and it is still found poor on knowledge $(2,5 \%)$. The attitude of respondents before IEC based on culture, it is generally at fair category (55\%) and (45\%) at poor category. After being given EIC based on culture, the attitude of the respondents rose up to the good category or $(90,0 \%)$ while at poor attitude at around $(2,5 \%)$.

From the result of different-test of mean (paired t-test), it can be seen that there is the influence of EIC based on culture on knowledge and attitude of respondents before and after EIC based on culture, with $\rho<\alpha 0.05$.

Notoadmodjo (2010), states that knowledge is the result of human sensing or the results of a person to the object through the senses owned by him/her. At the time of sensing in producing knowledge, it is strongly influenced by the intensity of attention and perception of the object. Much of a person's knowledge is acquired through the sense of hearing (ears) and the sense of sight (eye). It starts from awareness in the sense of knowing about the stimulus, then feels interested in the stimulus or object and finally weighs good or bad of the stimulus for him. Finally, the person will start to do something with what is desired by the stimulus so that ultimately the subject has been behaving in accordance with knowledge, awareness and attitude toward the stimulus. Therefore, for this research, respondents are easily attracted to the stimulus that is information about cervical cancer because it has been packaged in the form of song composition where the music is commonly heard, sang and danced by the Karo community so as to facilitate the increase of knowledge and attitude of respondents.

This research is in line with Oktarina's research (2014) which states that dance can be used as a medium of promotion of Posyandu activities that it may affect the interest. As a result, there is an increase of participation of the community to come to Posyandu. Hart (2013), also stated that special community art activities such as singing groups are potential for health promotion in the community.

\subsection{The Effect of Counseling on Cervical Cancer Knowledge and Attitude}

From Table 3, it can be seen that the level of knowledge of respondents before the counseling is generally poor $(75,0 \%)$ and fair at $(20,0 \%)$. While with counseling, knowledge level rose up to good category $(77,5 \%)$ and at poor category was still found at (7,5\%). Attitudes of respondents who were given counseling, generally also in the category fair at $(77,5 \%)$, but there are still $(20,0 \%)$ at the poor category. After being given counseling, the respondents' attitude is fair at around $(80,0 \%)$.

It can be also seen that there is influence of counseling about cervical cancer on knowledge with $\rho=0.001<\alpha$ 0.05 and there is influence of counseling on the attitude of respondents before and after given counseling, with $\rho 0,001$ $<\alpha 0.05$.

There is an increase on knowledge and attitude of respondents after being given treatment as a result of providing health education with counseling. Rini (2013) in her research stated that there was an increase of knowledge ( $p=$ $0,001)$ and attitude $(p=0,036)$ after counseling between control and intervention groups. Researchers use the media like power point slides in conducting counseling. Sulastri (2014) states that health education using power point slides as media is more effective to affect knowledge, attitude and behavior than using leaflets as tools. 


\subsection{The Effectiveness of IEC Based Culture and Counseling on Cervical Cancer}

From Table 4, it can be seen that the assessment of knowledge turns out to the relative homogeneous data or assumption of the same variation $(\rho 0.00<\alpha 0.05)$ and the result of difference-test average turns to $\rho 0.06>\alpha 0.05$ so Ho is accepted, meaning that there is no difference between IEC based on culture and counseling in improving knowledge.

The statistical test showed that there is no significant difference mean between IEC based on culture and counseling. However, it is descriptively seen that the average of higher knowledge with IEC based on culture at 36.75 compared to the average of knowledge through counseling at 35.65. This is because the information received is similar to the interest with the stimulus (information about cervical cancer). This is because respondents in both groups, they just received information regarding cervical cancer.

On the assessment of attitude, it turns out to the relative homogeneous data or the assumption of the same variation ( $\rho 0.640>\alpha 0.05$ ) and the result of the average of different-test turned out to be $\rho 0.001<\alpha 0.05$ so Ho is rejected, meaning that there is an average difference between the EIC based on culture and counseling in improving attitude. Thus, the EIC based on culture is more effectively to improve the attitude rather than through counseling. This situation may occur because the stimulus in the intervention group, information about cervical cancer is more easily to deliver through biological terminology which is packaged in the form of composition of songs with the accompaniment of music. In this way, the messages are well known by the community through singing together with practicing Landek dance.

\subsection{Study Implications}

This study will provide a strategy for prevention of cervical cancer with the Karo culture-based IEC approach, as an early detection of cervical cancer, the existence of material on prevention of cervical cancer and IVA implementation procedures to overcome the culture of shame, worry about the results of positive and ongoing examination in early detection of cancer cervix in the village of Cinta Rakyat Merdeka District Karo Regency

This research can be a reference for the development of science, especially the science of public health and midwifery (the development of teaching materials for students, especially in the subjects of public health and reproductive health).

\subsection{Limitations of the Study}

There are some limitations for the current study. First, KIE based on Karo culture, for Health Promotion about prevention of cervical cancer is still limited to the Karo tribe. Second, The use of KIE based Karo culture in the prevention of cervical cancer is still limited in its implementation, namely at annual parties (Year work) and requires music (drum) so that it can be sung and danced (hedgehog) according to Karo culture. Third, This research is still limited, only in the village of Karo People's Love District

\subsection{Recommendations For Future Research}

Despite the previously mentioned limitations, this study was able to contribute to the body of evidence on the link EIC Based Culture and Counseling about Early Detection of Cervical Cancer: First, Health Promotion Officers or called promkes, from the Health Office and The Center of Community Health or Puskesmas are suggested to use songs and Landek dance on cervical cancer counseling activities as cervical cancer prevention. Second, Composed songs and dance (Landek) can be practiced in other areas of Karo District as the way to prevent cervical cancer.

\section{Conclusion}

The present study results supported the association between EIC Based Culture and Counseling about Early Detection of Cervical Cancer: first, There is the influence of EIC based on culture through composed songs and Landek dance on the knowledge before and after given intervention $(p=0,001)$. Second, There is the influence of EIC based on culture through composed songs and Landek dance on attitude before and after being given intervention $(\mathrm{p}=0,001)$. Third, There is the influence of counseling of cervical cancer on the knowledge before and after given intervention $(\mathrm{p}=0,001)$. Fourth, There is the influence of counseling on attitude before and after given intervention $(p=0,001)$. Fifth, There is no difference between EIC based on culture through composed song and Landek dance, and counseling to increase the knowledge $(\mathrm{p}=0.06)$. sixth, EIC based on culture is more effective than counseling in improving attitudes toward cervical cancer $(\mathrm{p}=0.001)$.

\section{Competing Interests Statement}

The authors declare that there are no competing or potential conflicts of interest regarding the publication of the paper. 


\section{References}

Anggraeni, N., \& Muhartati, M. (2015). Relationship between the Level of Knowledge of Cervical Cancer and the Behavior of WUS Conducting IV A Examination at the Puskesmas Banguntapan Bantul (Doctoral dissertation, STIKES'Aisyiyah Yogyakarta).

Aziz, M. F. (2016). Vaksin Human Papillomavirus: An alternative in controlling cervical cancer in the future. Indonesian Journal of Obstetrics and Gynecology.

Darmayanti, D., Hapisah, H., \& Kirana, R. (2016). Factors Associated with Cervical Cancer in Ulin Banjarmasin Hospital. Jurnal Kesehatan, 6(2).

Dwipoyono, B. (2009). Cancer Disease Control Policy (Cervix) in Indonesia. Indonesian Journal of Cancer, 3(3).

Giersing, B. K., Modjarrad, K., Kaslow, D. C., Okwo-Bele, J. M., \& Moorthy, V. S. (2016). The 2016 vaccine development pipeline: a special issue from the world health organization product development for vaccine advisory committee (PDVAC). Vaccine, 34(26), 2863-4. https://doi.org/10.1016/j.vaccine.2016.04.041

Hart, R. A. (2013). Children's participation: The theory and practice of involving young citizens in community development and environmental care. Routledge. https://doi.org/10.4324/9781315070728

Ismawarti, Sutaryo, S., \& Widyatama, R. (2011). Promise in Enhancing Knowledge, Attitudes and Behavior of Early Detection of Cervical Cancer in Study Members, Berita Kedokteran Masyarakat, 27(2), 2011.

Jiang, P., \& Yue, Y. (2014). Human Papillomavirus Oncoproteins And Apoptosis. Experimental and therapeutic medicine, 7(1), 3-7. https://doi.org/10.3892/etm.2013.1374

Khoiron, N. (2014). Effectiveness of Health Education Using Leaflet Media and Media Slide Power Point on Changes in Knowledge, Attitudes and Behavior of Early Detection of Cervical Cancer in PKK Mothers in the Work Area Puskesmas Kartasura Sukoharjo.

Mannava, P., Durrant, K., Fisher, J., Chersich, M., \& Luchters, S. (2015). Attitudes and behaviours of maternal health care providers in interactions with clients: a systematic review. Globalization and health, 11(1), 36. https://doi.org/10.1186/s12992-015-0117-9

Manoppo, I. J. (2016). The Relationship Between Parity And The Age Of Mother With Cervical Cancer In Prof. Kandou General Hospital Manado In 2014 Ivanna Junamel Manoppo Fakultas Ilmu Keperawatan. Universitas Klaba, 2(1).

Mirayashi, D. (2014). relationship between the level of knowledge about cervical cancer and participation in examining Visual Acetate Inspection at puskesmas Alianyang Pontianak. Jurnal Mahasiswa PSPD FK Universitas Tanjungpura, 1(1).

Notoatmodjo, S. (2010). Health Research Methodology. Jakarta: Rineka Cipta.

Nurwijaya, H. (2013). Prevent and Detect Cervical Cancer. Elex Media Komputindo.

Oktarina, Sasmito, L., \& Rahayu, S. (2014). Media Promosi "Ayo Nyang Posyandu" Tari Memengan di Banyuwangi, Jawa Timur. Buletin Penelitian Sistem Kesehatan, 17(2), 143-150.

Pimple, S., Mishra, G., \& Shastri, S. (2016). Global Strategies For Cervical Cancer Prevention. Current Opinion in Obstetrics and Gynecology, 28(1), 4-10. https://doi.org/10.1097/GCO.0000000000000241

Prandana, D. A. (2013). Cervical Cancer Patients in RSUP H. Adam Malik Medan tahun 2011. e-jurnal Fakultas Kedokteran USU, 1(1).

Rahmiyati, N. (2016). The Model of Community Empowerment through the Application of Appropriate Technology in Kota Mojokerto. JMM17: Jurnal Ilmu Ekonomi dan Manajemen, 2(02).

Romadani, D. I. (2014). Effectiveness Of Health Promotion As Early Detection Of Ceramic Cancer To Reduce Death Numbers. In Prosiding Seminar Nasional \& Internasional (Vol. 2, No. 2).

Sari, S. L. (2012). Relationship between the Level of Knowledge and Early Behavior of Cervical Cancer Prevention in Patients at the Clinic Seroja Kota Kediri. STRADA Jurnal Ilmiah Kesehatan, 1(1), 30-36.

Soedoko, R. A. (2001). Cervical Cancer.

Sulastri, Romadani, D. I. Andari Aulia. (2014). The effectiveness of Promkes as an early detection of cervical cancer to reduce mortality.

Sulistiowati, E., \& Sirait, A. M. (2015). Knowledge of Risk Factors, Behavior and Early Detection of Cervical 
Cancer by Visual Inspection of Acetic Acid (IVA) in Women in the District Bogor Tengah, Kota Bogor. Buletin Penelitian Kesehatan, 42(3 Sep), 193-202.

Surbakti E.Mangkuji B, Ginting B .2017, Influence Of Cancer Fatalism And Family Support Against Delay Cervical Cancer Sufferers Seek Treatment At The Hospital Center H.Adam Malik Medan Indonesia

Suryandari, A. E. (2014). Knowledge Relationship, Cancer Fatalism And Age Women Awareness (Wus) In Test Assessment Tes IVA. Kesmas Indonesia, 6(03), 208-222.

Suwiyoga, K. (2016). Kanker Serviks: Fatal Malignancies That Can Be Prevented. Indonesian Journal of Obstetrics and Gynecology.

Tengah, D. K. P. J. (2014). Health profile of Central Java province tahun 2012. Semarang: Dinkesjateng.

Ulfah, (2016). The Influence Of Treatment Methods On Knowledge And Attitude Of Youth Teachers In Preventing Service Cancer in SMK SWAGAYA 2 Purwokerto (Doctoral dissertation, Universitas Muhammadiyah Purwokerto).

Vanesa, L. (2018). Health Education Effect on Wus Interest to Do Iva Examination In Puskesmas Bakunase. CHMK Midwifery Scientific Journal, 2(2), 20-20.

\section{Copyrights}

Copyright for this article is retained by the author(s), with first publication rights granted to the journal.

This is an open-access article distributed under the terms and conditions of the Creative Commons Attribution license (http://creativecommons.org/licenses/by/4.0/). 